\title{
The Role of Vegetation in Conservation of Small Rivers in the Middle Volga
}

\author{
Kurbanova S.G.a \\ Prokhorenko N.B. ${ }^{b}$
}

a Kazan Federal University, Institute of Management, Economics and Finance, Kazan, 420008, Russia
${ }^{b}$ Kazan Federal University, The Institute of Fundamental Medicine and Biology, Kazan, 420008, Russia

Doi:10.5901/mjss.2015.v6n1s3p242

\begin{abstract}
The numerous cases of the upper headwaters drying are observed in the plains of the Middle Volga region. The reasons of the streamflow change pertain to the reduction of forest vegetation and the change of its species composition. The studies have shown that over the past 120 years the quantity of the first-order watercourses has reduced by 1.5 times in the areas of coniferous and mixed forests, whilst in the forest-steppe zone the quantity of the first-order watercourses has decreased by nearly 2.5 times.
\end{abstract}

Keywords: the river network, infiltration, forest types, phyto-diversity, forest regeneration.

\section{Introduction}

Over the past 200-250 years human activities have led to significant transformations in natural landscapes. In most parts of the Middle Volga they transformed to natural-anthropogenic, and purely anthropogenic (agricultural and industrial).The condition of the small rivers' flows can indicate the impact of deforestation and plowing areas [5]. Many researchers have marked the structural change of the river network pattern in the areas from the middle taiga to steppe in the territory of the Middle Volga, as well as in the countries of Western and Central Europe [7].

They are manifested in disappearance of the upper parts of the river network, and in transformation of streams from constant to temporary ones. As a consequence, we observe the decrease of the total river network density, the reduction of the tributaries order, where the II-order rivers (as per Filosov-Straller's classification) turn into the I-order streams. However, the question of the determining factors having the direct impact on the rivers degradation is still being discussed.

An important component of the hydrological cycle in ecosystems is vegetation and its species composition $[1,2$, 11]. One of the important aspects of ecological and hydrological studies is the identification of the role of vegetation in the regulation of moisture and its outflow through transpiration, infiltration, as well as the formation of surface and subsurface flows.

\section{The Research Method and Sources}

To determine the effect of different vegetation types and its species diversity on groundwater recharge, the detailed studies and descriptions of phytocenoses in different forest zones of the Middle Volga, have been carried according to the conventional geobotanic procedure [9]. To identify the role of forests and treeless basins, the researches used the study materials on water collection received by the former USSR Hydrometeorological Service in paired water catchment areas (forest and artificially deforested areas) in different parts of the country. The analysis of the direction and the change rate of the river network pattern as well as its quantitative evaluation were performed using heterogeneous-in time-mapping of materials, ranging from the late 19th to the 21st century. In addition, satellite images were used. The interpretation of satellite images was performed using SAS Planet and Google Earth. To verify the obtained results, the field expeditions were carried out.

\section{The Research Results}

The landscapes of the Middle Volga area considerably vary in vegetation types, species composition and diversity, as 
well as in soil cover. We can distinguish 3 types of the modern natural-anthropogenic landscapes by the degree of the natural areas transformation caused by the human activity: forest, forests -field and field types [7].

The forest landscapes are characterized by forest areas from $70 \%$ or more and the internal zonation. In the northern part of the Middle Volga, in the southern taiga subzone, the coniferous and mixed forests are widespread. In the central part of the Middle Volga, in the areas of mixed and deciduous forests, the deciduous plantings are more common. The forest-field landscapes are relatively low in forest coverage - from 30 to 70\%, feature a developed meadow-steppe and steppe vegetation with the forest patches. They are found in the south of the forest area and dominate in the foreststeppe zone. The specificity of the field landscapes is determined by a large area of development (70\%), whilst the of the natural vegetation has remained in less than $30 \%$ of the territory. The agricultural plots are presented in varying degrees in all natural zones of the Middle Volga.

As noted by the domestic and foreign authors, forests, compared to other types of vegetation, have the most significant impact on the hydrological cycle $[10,12]$. The optimal hydrological function is performed by natural forests with high species diversity. During the drillings, the expeditions of Kazan Federal University discovered that the depth of the aquifer in the forested landscapes is $10-15 \mathrm{~m}$, while in forest-field and field areas, it reaches 25-30m (Fig. 1).

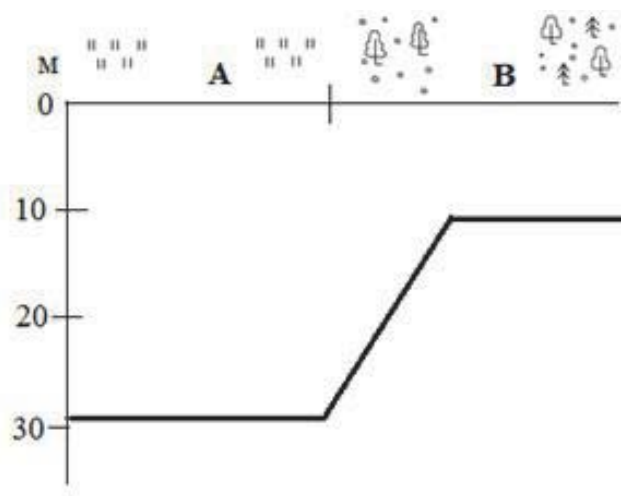

Fig. 1. The depth of the aquifer in forest-field and field landscapes (A) and in forest landscapes (B) of the Middle Volga.

The hydrological and field studies have revealed that territory deforestation determines the change in consumption of snow moisture in various natural-anthropogenic landscapes, leading to the reduction of infiltration and increase surface runoff (Fig. 2). These hydrological changes determine the lowering of groundwater levels in forest- field and field landscapes. A similar pattern is marked by J. Buchtele et al [3] in the Czech Republic, where deforestation has led to an increased surface runoff.

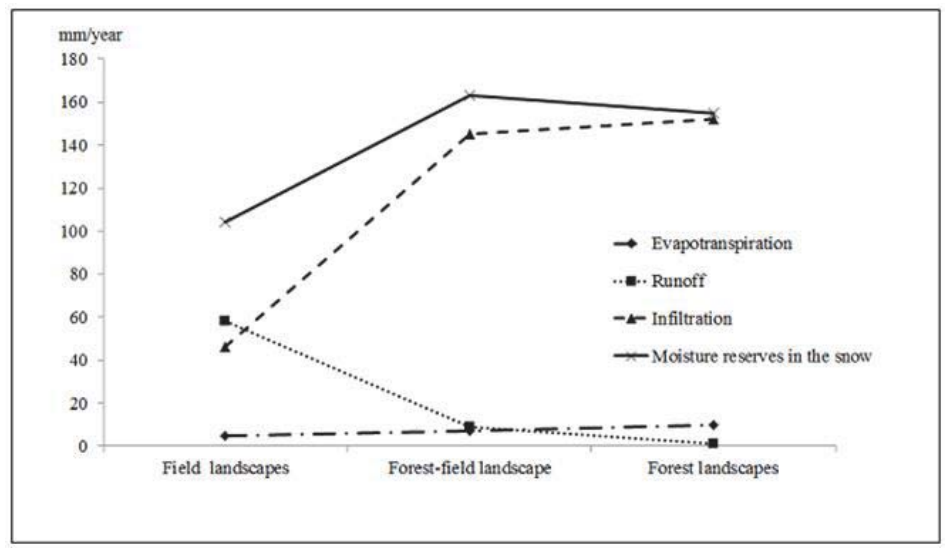

Fig. 2. The impact of vegetation on the groundwater recharge in various natural and anthropogenic landscapes

The regulation of the water cycle, according to various authors, is largely influenced by the biotic factors, such as plant species composition, especially their morphology, tree stand density, and others $[2,8,11,14]$. The typological analysis of vegetation has shown that in the central part of the Middle Volga (Pre-Kama areas), within the southern taiga subzone and mixed forests areas, there are well-developed of pine and spruce forest formations, as well as pine-deciduous, 
spruce-deciduous and spruce-silver fir-deciduous forest subformations.

Besides the relatively-indigenous forests, there are widespread secondary long- and short-derivative coniferousleaved, broad-leaved and small-leaved forests. On the whole, the contribution of coniferous types in Pre-Kama area reaches $40 \%$, whilst in deciduous types it does not exceed $60 \%$ of the total forested area [9].

Forest landscapes have also preserved in the Pre-Volga area, in the forest Zasuriye and Trans-Volga regions (The Cheremshan River valley). The Northern Pre-Volga region as well as the south-western regions of Pre-Kama to be situated to the zone of broad-leaved forests, whereas the southern Pre-Volga and Trans-Kama regions refer to the foreststeppe zone. In these regions, the forest vegetation is formed by the typical native and long-derivatives of lime trees and oak forest formations. On sandy substrates, along the river valleys, the fragments of pine forests grow. Whereas, among the forest vegetation of the Pre-Volga and the Trans-Kama regions, the biocenosis with the dominance of coniferous species does not reach more than 14\%. Most of the forested area here is formed by the deciduous forests.

In determining the role of vegetation in the groundwater recharge, the most widely spread in the Pre-Kama and the Pre-Volga regions long-derivative pine forests with shrubs of boreo-nemoral type, as well as herbal limes of nemoral structure have been studied. The age of the studied forest stands is 80-140 years. The crown cover of pine plantings varies from $40-80 \%$, and $60-70 \%$ for lime trees. The total projective cover of shrubs in phytocenoses reaches $30-40 \%$, and $50-80 \%$ of grass tier. The species diversity of the vascular plants in the phytocenoses of these forest types ranges from 25 to 70 species / 250m2; whereas, the phyto-diversity in pine forest with shrubs averages $40 \pm 3,5$ species per $250 \mathrm{~m} 2$, in herbal limes forests has similar figures ( $43 \pm 3,2$ species per $250 \mathrm{~m} 2$ respectively). The Relatively high diversity of the plant species in different tiers increases the infiltration rate and the formation of the surface runoff. Similar conclusions on the enhanced infiltration in ecosystems with high species diversity, leading to the reduction of soil erosion, is expressed by a number of authors $[4,15]$.

Different plant species retain and transfer water in the soil, to various degrees. The studies have shown that the coniferous types, with dark-coniferous plantations among them, retain a relatively high level of precipitations, they have a relatively low transpiration and a high hygroscopicity of the forest floor [6]. A specific microclimate is created in the coniferous forests. Thus, according to $\mathrm{M}$. Tesař et al. [13], on a sunny day under the canopy of spruce and deciduous forests, in a $5 \mathrm{~cm}$ layer above the soil, the temperature is $7^{\circ} \mathrm{C}$ lower than in the treeless areas located in similar conditions, which provides a relatively smaller evaporation and, consequently, a greater retention of moisture in the soil.

The analysis of the map, literary and expedition studies have shown the following results. The dramatic changes have taken place throughout the forest and steppe zone landscapes since the late 19th century to the present time, with the dominating agricultural influence. Depending on the extent of human impact a clear trend in the length reduction of the I and II order streams is observed, with their often complete disappearance and transition to dry ravine. More detail, this process can be observed on the example of the three river basins, varying in the degree of the human activity impact and in their vegetation composition. These are: the Kazanka river, the left tributary of the Volga river - in the southern taiga subzone (coniferous and mixed forests); the Arya river - in the deciduous forest area (broad-leaved and smallleaved forests); the Big Sulcha river - in the forest-steppe zone (broad-leaved forest, meadow and steppe vegetation).

Thus, during the last 120 years the forest area of the Western Pre-Kama region has decreased by 3.5 times on average, the number of the I order streams of the Kazanka river has decreased from 328 to 274, the II order streams from 86 to 66 (See Table. 1). The detailed studies have shown that the streams length on the right bank of the Kazanka river have increased from 219 to $360 \mathrm{~km}$, whilst the left tributaries' length has decreased from 169 to $120 \mathrm{~km}$. This is caused by the drainage of the groundwater and the vegetation composition of the right bank, where the coniferous-smallleaved forests are situated, contributing to the conservation of soil and retaining of the groundwater and river deepness.

Table 1. The changing nature of the river network and forest coverage from 1870 to 1990 years [7]

\begin{tabular}{|l|l|c|c|}
\hline Region & Index & $1870 \mathrm{~s}$. & $1990 \mathrm{~s}$. \\
\hline \multirow{3}{*}{ The western Pre-Kama region, The Kazanka river } & Forestation of the region (\%) & 38,8 & 11,1 \\
& The number of the I order streams/ length, $\mathrm{km}$ & $328 / 291,8$ & $274 / 431,9$ \\
& The number of the II order streams/ length, km & $86 / 174,3$ & $66 / 234,4$ \\
\hline \multirow{3}{*}{ The Northern Pre-Volga region, the Arya river } & Forestation of the region (\%) & 26,6 & 18,3 \\
& The number of the I order streams/ length, km & $31 / 75,3$ & $24 / 48$ \\
& The number of the II order streams/ length, km & $9 / 43,4$ & $8 / 16,8$ \\
\hline \multirow{2}{*}{ The western Trans-Kama region, The Big Sulcha river } & Forestation of the region (\%) & 51,1 & 22,6 \\
& The number of the I order streams/length, km & $106 / 105,7$ & $47 / 100,7$ \\
& The number of the II order streams/ length, km & $27 / 59,7$ & $11 / 70,1$ \\
\hline
\end{tabular}


During the study period in the northern Pre-Volga region, the forest area has decreased by 1.5 times, with part of the territory transferring into forest-field landscapes. The right bank of the Arya river with mixed and deciduous formations has become deforested and now refers to the "field" type landscapes. This has reflected in the reduction of the I order streams number - from 31 to 24, while the II order streams number has remained unchanged.

Over the same period of time, the forest area in the Western Trans-Kama region has decreased by more than 2 times, and is now generally represented by the "field" type landscapes. This has resulted in the Sulcha's I and II order streams decrease by 2.3-2.5 times, numbering from 106 to 47 and from 27 to 11, respectively. The structure of the Big Sulcha river has become greatly simplified (Fig. 4).
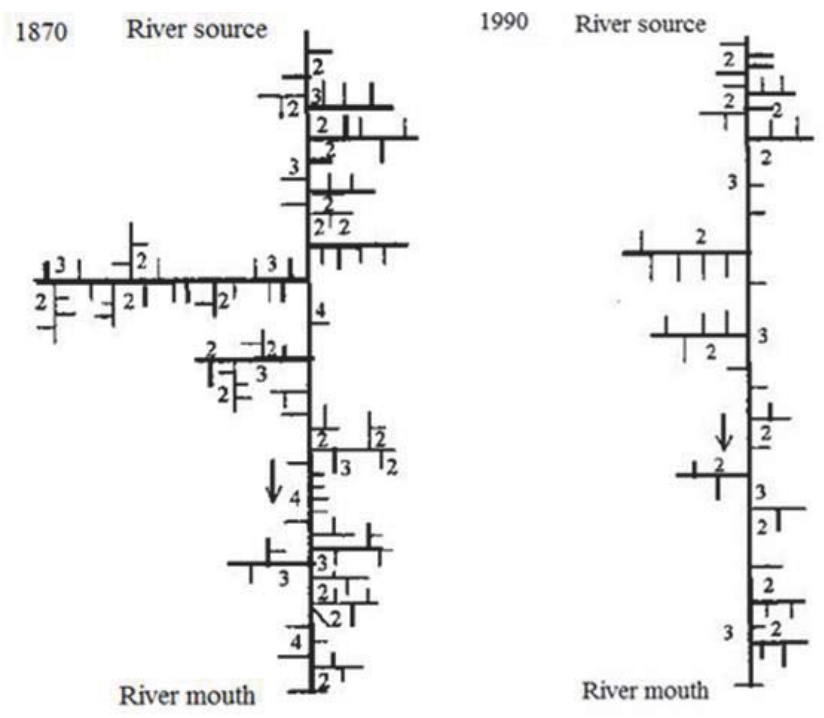

Fig. 4. The structure of the Big Sulcha river network (2,3,4 - order rivers)

The reduction of the I order streams number and their total length is most pronounced in the Western Trans-Kama region. The sharp reduction in the number of upper parts of the river network is impacted by the dominance of meadow-steppe and steppe vegetation plots in the region and the low contribution of the coniferous plantings. To a lesser extent the degradation of the small streams is observed on the Kazanka river. This is explained both by a greater percentage of forest land in the Pre-Kama area and the coniferous and mixed forests presence in its basin.

In the studied territory, the forest vegetation restoration occurs due to the presence of pine cultures. Thus, in the Pre-Kama area, the pine tree planting in the Nurminka river valley, has led to the restoration of springs and reservoir waters for the 20-year period. Consequently, pine forests stimulate infiltration and the replenishment of the subsurface runoff. According to our data, the artificially-planted pines of 30-50 years of age are distinguished by a simplified structure with a weak development of shrubs and a sparse grass cover (the projective cover it is not more than $50 \%$ ). Their species diversity is average $26 \pm 1,2$ species on/ $250 \mathrm{~m} 2$, which is 2 times lower than in the communities of natural origin. Thus, for reforestation we should plant coniferous, coniferous-small-leaved stands as the most dynamically stable types of forests, corresponding to the zonal features of the region.

\section{Conclusion}

The anthropogenic development of the landscape has led to a decrease of the forest area and virgin lands, as well as to the degradation of small rivers in all natural zones of the Middle Volga, determining the change in the small rivers structure, reducing the number of their upper-level parts.

The forest vegetation compared to the meadow-steppe and steppe type leads to a greater retention of moisture in the soil, providing high standing groundwater at the depth of $10-15 \mathrm{~m}$. A high forest cover of the basins provides an abundance of water-permeable soil layers. With the destruction of forests the runoff increase and the infiltration of precipitations reduces. The small rivers fed by the waters of these depths quickly lose their low flow and get dry.

In the forest and steppe zones, where the plowed areas do not exceed $70 \%$ and the coniferous, mixed and deciduous forests are present, the length of the I order streams has reduced by 1,5 times over the past 120 years. On 
anthropogenically developed areas, with the dominating field landscapes and wild herbaceous vegetation, the number of small streams has decreased by 2.5 times. The river basins covered by the coniferous and mixed forests, have been deforested to a lesser extent, since the conifers contribute to a higher rate of precipitations, snow and rain transfer into the groundwater.

\section{References}

Asbjornsen H., Goldsmith G. R., Alvarado-Barrientos M. S., Rebel K., OschF.P., Rietkerk M., Chen J., Gotsch S., Tobo'n C., Geisser D. R. Go'mez-Tagle A., Vache K. and Dawson T. E. Ecohydrological advances and applications in plant-water relations research: a review / Journal of Plant Ecology, 2011. V. 4 (1-2), pp. 3-22.

Bredemeier M., Cohen S., Godbold D.L., Lode E., Pichler V., Schleppi P Forest Management and the Water Cycle. Series: Ecological Studies, 2011.V. 212, 531p.

Buchtele J., Buchtelová M., Tesař M. Role of vegetation in the variability of water regimes in the Šumava Mts forest / Biologia, 2006.V. 61 (19), pp. 246-250.

Hu L.-J., Li P., Guo Q. Positive plant diversity-soil stability relationships are mediated through roots in the Songnen grassland: chronosequence evidence / Not Bot Horti Agrobo, 2013.V. 41(2), pp. 626-637.

Loskutov C.P., Shapchenkova V.A., Vedrova E.F. The hygroscopic features of the coniferous and deciduous forests floor in the Mid Siberia Area // The Siberian Ecological Magazine, 2013. V.20 (5). pp. 695-702.

Mozzherin V.I., Kurbanova S.G. Human activity in channel erosion systems of the Mid Volga area. Kazan: "Art Design", 2004. 128p.

Pichler V., Durkovic J., Capuliak J., Pichlerova M. Altitudinal variability of the soil water content in natural and managed beech (Fagus sylvatica L.) forests / Polish Journal of Ecology, 2009. Vol. 57(2), pp. 313-319.

Prohorenko N.B., Kurbanova S.G, Glushko. The influence of the forest vegetation on the minor rivers condition in Tatarstan // RAS, Samara Scientific Centre Newsfeed, 2014.V. 16. №1(3). pp. 886-891.

Šach F., Švihla V., Černohous V., Kantor P. Management of mountain forests in the hydrology of a landscape, the Czech Republic / J. Forest Science, 2014. V. 60, pp. 42-50.

Střelcová K., Mind'áš J., Škvarenina J. Influence of tree transpiration on mass water balance of mixed mountain forests of the West Carpathians / Biologia, 2006. V. 61 (19), pp. 305-310.

Štekauerova V., Nagy V., Kotorova D. Soil water regime of agricultural field and forest ecosystem // Biology, V. 61, Issue 19, pp. 300304.

Kinossian, N. (2013). Stuck in transition: Russian regional planning policy between spatial polarization and equalization. Eurasian Geography and Economics, 54 (5-6), pp. 611-629.

Tesař M., Sír M., Lichner L'. \& Zelenková E. Influence of vegetation cover on thermal regime of mountainous catchments / Biologia, 2006. V. 61 (19), pp. 311-314.

Yin Z., Ouyang H., Xu X., Zhou C., Zhang F., Shao B. Estimation of Evapotranspiration from Faber Fir Forest Ecosystem in the Eastern Tibetan Plateau of China Using SHAW Model / J. Water Resource and Protection, 2010. V. 2, pp. 143-153.

Komarova, V.N., Zjablova, O.V., Denmukhametov, R.R. An infrastructure factor in regional competitiveness. Mediterranean Journal of Social Sciences, 5 (18 SPEC. ISSUE), pp. 355-360.

Zhenhong W. Relationship between plant species diversity and soil erosion on different secondary succession phases of a semi-humid evergreen broad-leaved forest / 13th International Soil Conservation Organisation Conference - Brisbane, July. Conserving Soil and Water for Society: Sharing Solutions, 2004, pp. 1-4.

Gaisin, I.T., Beketova, S.I., Gaisin, R.I. Competence-based approach as an effective way to increase the level of training of geographers in universities // Life Science Journal 2014;11(11 s)C.166-170.http//www.lifesciencesite.com 